University of Nebraska - Lincoln

DigitalCommons@University of Nebraska - Lincoln

Agronomy \& Horticulture -- Faculty Publications

Agronomy and Horticulture Department

2007

\title{
Plant species richness in relation to pasture position, management, and scale
}

John A. Guretzky

University of Nebraska-Lincoln, jguretzky2@unl.edu

Kenneth J. Moore

lowa State University, kjmoore@iastate.edu

C. Lee Burras

lowa State University, Iburras@iastate.edu

E. Charles Brummer

University of Georgia, brummer@uga.edu

Follow this and additional works at: https://digitalcommons.unl.edu/agronomyfacpub

Part of the Plant Sciences Commons

Guretzky, John A.; Moore, Kenneth J.; Burras, C. Lee; and Brummer, E. Charles, "Plant species richness in relation to pasture position, management, and scale" (2007). Agronomy \& Horticulture -- Faculty Publications. 589.

https://digitalcommons.unl.edu/agronomyfacpub/589

This Article is brought to you for free and open access by the Agronomy and Horticulture Department at DigitalCommons@University of Nebraska - Lincoln. It has been accepted for inclusion in Agronomy \& Horticulture -Faculty Publications by an authorized administrator of DigitalCommons@University of Nebraska - Lincoln. 


\title{
Plant species richness in relation to pasture position, management, and scale
}

\author{
John A. Guretzky, ${ }^{1}$ Kenneth J. Moore, ${ }^{2}$ C. Lee Burras, ${ }^{2}$ and E. Charles Brummer ${ }^{3}$ \\ 1. The Samuel Roberts Noble Foundation, 2510 Sam Noble Parkway, Ardmore, OK 73401, USA \\ 2. Department of Agronomy, Iowa State University, Ames, IA 50011-1010, USA \\ 3. Center for Applied Genetic Technologies, University of Georgia, 111 Riverbend Road, Athens, GA 30602-6810, USA \\ Corresponding author - J. A. Guretzky, jguretsky@unl.edu
}

\begin{abstract}
The objective of this research was to describe how landscape position, grazing management, and scale affected overall plant species richness and species richness per functional group in temperate pastures located in the central United States. The effects and interactions of summit, backslope, and toeslope positions and continuous, rotational, and nongrazed stocking systems on species richness were examined at sample scales of $0.18 \mathrm{~m}^{2}$ and $4.5 \mathrm{~m}^{2}$. Landscape position explained $40-63 \%$ of species richness variation at $0.18 \mathrm{~m}^{2}$ compared to $3-26 \%$ at $4.5 \mathrm{~m}^{2}$ for overall, perennial, perennial grass, vegetative-spreading grass, perennial herb, and perennial $\mathrm{N}_{2}$-fixing herb (legume) functional groups. Grazing management, in contrast, explained $22-35 \%$ of species richness variation for overall, perennial, annual-biennial, perennial grass, and perennial bunchgrass functional groups at $0.18 \mathrm{~m}^{2}$ compared to $30-43 \%$ of their variation at $4.5 \mathrm{~m}^{2}$. Landscape position and stocking system mostly did not interact. Overall species richness averaged 11.7, 14.3, and 10.3 on summits, backslopes, and toeslopes, respectively, and 14.8, 12.9, and 8.7 within the continuous, rotational, and nongrazed systems, respectively, at the $4.5 \mathrm{~m}^{2}$-scale. Backslope positions supported more species than summits and toeslopes regardless of scale, with differences that appeared related to total vegetation production and aboveground competition. Continuously and rotationally stocked pastures also supported more species than nongrazed pastures, effects that were consistent across functional types and scales. Increased scale enabled detection of a greater number of species per unit area but reduced the percentage of species richness variation explained by pasture position and management.
\end{abstract}

Keywords: grazing management, pasture species diversity, legume diversity, forage legumes, continuous grazing, rotational grazing

\section{Introduction}

A current hypothesis is that pasture ecosystems depend on species diversity. The loss of biodiversity on local, regional, and global scales has prompted scientists to question whether these losses impair ecosystem functions such as biomass production (Hector et al., 1999; Tilman et al., 2001), litter decomposition (Hector et al., 2000; Knops et al., 2001), nutrient cycling (Hooper, 1998; Hooper and Vitousek, 1999), and resistance to invasion by weeds (Crawley et al., 1999; Dukes, 2002). Sanderson et al. (2004) examined implications of this research for temperate forage and grazing land ecosystems and observed that benefits of increased species diversity were extrapolated to forage and grazing land ecosystems with little supporting data and that most information on the potential benefits of plant diversity arose from studies of synthesized grasslands that had not included domestic livestock.

Topographic and soil variation, intrinsic properties of many grazing lands, suggests that a diversity of species may be necessary to optimize production and quality of forage spatially and temporally. Harmoney et al. (2001) examined whether variation associated with landscape position and grazing management affected forage production and legume diversity in temperate pastures. Results suggested that a diverse mixture of legumes sowed on backslope positions in permanent, low-input pastures could enhance the production and quality of forage as a result of positive effects of legumes on soil- 
plant nitrogen balances. In a follow up of this research, landscape position and grazing management effects on overall species diversity and functional composition of these pastures were examined (Guretzky et al., 2005). Grazing reduced cover of the dominant, perennial vegetative grasses, smooth brome (Bromus inermis Leyss.) and reed canarygrass (Phalaris arundinacea L.) and encouraged greater diversity and cover of subdominant grasses, legumes, and non- $\mathrm{N}_{2}$-fixing forbs, effects most evident on backslopes.

The objective of this study was to examine how landscape position, grazing management, and scale affected overall plant species and functional group species richness in temperate pastures located in the central United States. Species richness was determined at $0.18 \mathrm{~m}^{2}$ and $4.5 \mathrm{~m}^{2}$-scales from data collected from four experimental pastures that each contained three landscape positions (summit, backslope, and toeslope) and three stocking systems (continuous, rotational, and nongrazed). It was hypothesized that scale would affect the ability of landscape position and grazing management to explain species richness variation and characterize species richness patterns.

\section{Materials and methods}

Research was initiated in 1995 at the Iowa State University Rhodes Research Farm, USA $\left(41^{\circ} 52^{\prime} \mathrm{N}, 93^{\circ} 10^{\prime} \mathrm{W}\right)$. Six cool-season grass pastures, each of which had summit, backslope, toeslope, opposite backslope, and opposite summit landscape positions, were identified and interseeded with a mixture of alfalfa (Medicago sativa L.), biennial yellow sweetclover (Melilotus officinalis (L.) Pall), biennial white sweetclover (M. alba Medic.), birdsfoot trefoil (Lotus corniculatus L.), white clover (T. repens L.), red clover (T. pratense L.), kura clover (T. ambiguum Bieb.), cicer milkvetch (Astragalus cicer L.), berseem clover (T. alexandrinum L.), striate lespedeza (Kummerowia striata (Thunb.) Schindler), and annual white sweetclover ( $M$. alba Medic.). Of the six pastures, four were 1.2 ha and two were 1.0 ha and three had north-south orientations and three had east-west orientations. Slopes ranged from $0 \%$ to $5 \%$ on summit and toeslope positions and $10 \%$ to $24 \%$ on backslope positions. Summit and backslope positions consisted of Downs (fine-silty, mixed, superactive, mesic Typic Hapludalf) soils, and toeslope positions consisted of Colo (fine-silty, mixed, superactive, mesic Cumulic Haplaquoll) and Ackmore (fine-silty, mixed, non-acid, mesic Aeric Fluvaquent) soils (Oelmann, 1981).

In spring 1996, each pasture was subdivided into three equal-sized paddocks that crossed in a perpendicular manner the summit, backslope, toeslope, opposite backslope, and opposite summit positions. The three paddocks were randomly assigned a stocking system: continuous, rotational, or nongrazed (control). Stocking rates were similar among the continuous and rotational systems: 9.4-10.1 animal unit months (AUM) ha ${ }^{-1}$. In most years, the continuously stocked paddocks were grazed by one to two mature, non-lactating beef cows from midMay through mid-August and during November if forage was available. Paddocks assigned rotational stocking were grazed by eight to nine mature, non-lactating beef cows across a $4 \mathrm{~d}$ span, three times annually (May, July, and November). The intent of the rotational system was to minimize selective grazing, remove the majority of forage within a short time period, and increase the period of rest between grazing events relative to the continuous stocking system. Patch grazing appeared to be greater within the continuous system as sward heights ranged from $<5 \mathrm{~cm}$ in heavily utilized areas to $>20 \mathrm{~cm}$ in under utilized areas. Sward heights appeared more uniform following rotational stocking: $10-20 \mathrm{~cm}$ on summits and backslopes and $20-30 \mathrm{~cm}$ on toeslopes. Grazing began on the same date within each paddock and replicate and continued annually through November 2002. Cows were removed from the continuously stocked paddocks when residue height for the majority of the herbage was $<13 \mathrm{~cm}$ and from the rotationally stocked paddocks after the $4 \mathrm{~d}$ period of each grazing event. Nongrazed plots were mowed annually in mid-November.

Data were collected from the four 1.2 ha pastures in May and July of 2000 and 2001 to examine effects of pasture position and management on vegetation species cover. Of the four pastures, two had north-south orientations and two had east-west orientations. Each sampling period ninety to hundred $0.18 \mathrm{~m}^{2}$ quadrats were randomly distributed and sampled within each stocking system (paddock) for a total of $270-300$ per pasture. After two seasons and 2 years of data collection in the four pastures, a total of 4484 quadrats were sampled. Plant species occurring within each quadrat were identified and classified as perennial grasses, perennial herbs, and annuals-biennials. The perennial grasses group, consisting largely of cool-season grasses considered desirable within these pastures, was subdivided into grasses capable of spreading vegetatively and bunch-types. Perennial herbs were subdivided into legumes and non- $\mathrm{N}_{2}-$ fixing forbs. Most of the legumes still persistent since initial establishment in 1995 were perennial. Few species overall were annuals and biennials. Thus, they were combined into one group consisting of annual and biennial grasses and herbs.

Although 270-300 quadrats were sampled in each pasture during each sampling period, area differences resulted in an unequal number of quadrats sampled per landscape position. Thus, overall species richness and species richness per functional group was determined from of a random subset of 25 samples from each position (3) of each stocking method (3) and pasture replicate (4) combination for a total of 900 samples. Overall species richness and species richness per functional group at the $0.18 \mathrm{~m}^{2}$-scale was determined from the means of the 25 samples. For species richness estimates at the $4.5 \mathrm{~m}^{2}$-scale, means were not calculated, but rather, the same subset of 25 samples were com- 
bined to form one sample per landscape position, stocking system, and pasture replicate combination. The limited area of toeslope positions in the pastures restricted the species richness-scale analysis to 25 samples and the scale of $4.5 \mathrm{~m}^{2}$. The $4.5 \mathrm{~m}^{2}$ samples were subsequently combined into $37.5 \mathrm{~m}^{2}$ and $162 \mathrm{~m}^{2}$-scales to model species richness-area relationships across the pastures.

The experiment was a randomized complete block design. Landscape positions and stocking systems were arranged as a split block within each of the four pasture replicates. The experiment was analyzed using the GLM procedure within the Statistical Analysis System software (SAS Institute Inc., Cary, NC). To compare how scale affected the ability of positions and management systems to explain species richness variation, measures of effect size or the degree of association between the effects and the dependent variables were calculated as the ratio of the effect variance to the total variance: $100 \times($ sum of squares effect $_{\text {sum of squares }}$ total $)$ for each scale. Single degree of freedom contrasts were used to examine mean differences among stocking systems and landscape positions when main effects were significant $(P \leq 0.05)$. Landscape position and stocking system were considered fixed and pasture replicates random. Because previous analyses showed that effects of aspect, season, and year on species composition and diversity were mostly insignificant (Harmoney et al., 2001; Guretzky et al., 2005), these factors were not considered further.

\section{Results}

\subsection{Scale effects}

Scale affected the percentage of plant species richness variation explained by landscape position and grazing management. For overall, perennial, perennial grass, perennial vegetative grass, perennial herb, and perennial $\mathrm{N}_{2}$-fixing herb functional groups, landscape position significantly explained 3-26\% of species richness variation at the $4.5 \mathrm{~m}^{2}$-scale compared to $40-63 \%$ at $0.18 \mathrm{~m}^{2}$. Landscape position did not significantly affect species richness of annual-biennial, perennial bunchgrass, and perennial non- $\mathrm{N}_{2}$-fixing herb functional groups at either scale $(P>0.05)$. Grazing management, in contrast, significantly explained $22-35 \%$ of species richness variation for overall, perennial, annual-biennial, perennial grass, and perennial bunchgrass functional groups at $0.18 \mathrm{~m}^{2}$ compared to $30-43 \%$ of their variation at $4.5 \mathrm{~m}^{2}$. For vegetative-spreading grass, perennial herb, and perennial non- $\mathrm{N}_{2}$-fixing herb functional groups, grazing management significantly explained $10-17 \%$, $12-$ $16 \%$, and $14-21 \%$ of their variation, respectively, across the two scales. Landscape position and grazing management interacted once, affecting overall species richness at $0.18 \mathrm{~m}^{2}(P \leq 0.05)$. Across all functional groups, landscape position and grazing management interactions accounted for only $1-14 \%$ of species richness

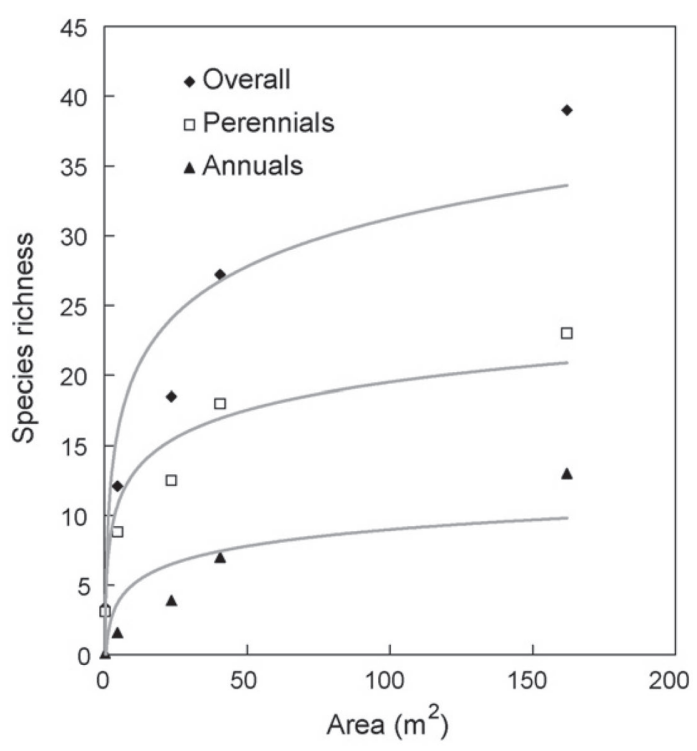

Figure 1. Species richness-area relationships derived from four 1.2 ha pastures at the Iowa State University Rhodes Research Farm, USA. For overall species: $y=5.0 \ln (x)+8.4$, $R^{2}=0.89$; perennials: $y=2.8 \ln (x)+6.4, R^{2}=0.92$; annuals-biennials: $y=1.7 \ln (x)+1.1, R^{2}=0.76$.

variation. Together grazing management and landscape position explained $70-81 \%$ of species richness variation at $0.18 \mathrm{~m}^{2}$ compared to $34-61 \%$ at $4.5 \mathrm{~m}^{2}$ for overall species, perennial, perennial grass, perennial herb, and perennial $\mathrm{N}_{2}$-fixing herb functional groups.

Species richness increased with scale in a logarithmic manner. When averaged across samples combined from the four pasture replicates, three landscape positions, and three stocking systems, 39 species overall were supported at $162 \mathrm{~m}^{2}$ (Figure 1). Of these species, 59\% were perennials, $33 \%$ were annuals-biennials, and $8 \%$ were unidentified grasses and herbs (data not shown). Among perennials, the pastures supported 8 grasses and 16 herbs. Five of the grasses were vegetative spreading and three were bunch-type species. Legumes reached a plateau of six species at $40.5 \mathrm{~m}^{2}$. Forbs comprised $63 \%$ of the perennial herb functional group at $162 \mathrm{~m}^{2}$.

\subsection{Landscape position effects}

Species richness of overall, perennial, perennial grass, perennial bunchgrass, perennial herb, and perennial $\mathrm{N}_{2}$-fixing herb functional groups were greater on backslopes than on summits and toeslopes at both $0.18 \mathrm{~m}^{2}$ and $4.5 \mathrm{~m}^{2}$ (Table 1). Backslopes supported similar species richness of perennial vegetative grasses, perennial non- $\mathrm{N}_{2}$-fixing herbs, and annuals-biennials as summits and toeslopes. Summits supported greater species richness of perennial grass, perennial vegetative grass, perennial herb, and perennial $\mathrm{N}_{2}$-fixing herb functional groups than toeslopes at $0.18 \mathrm{~m}^{2}$ but not $4.5 \mathrm{~m}^{2}$ (Table 1). Species richness of perennial bunchgrass, peren- 
Table 1. Landscape position (summit (S), backslope (B), and toeslope (T)) effects on species richness of overall, perennial, annualbiennial, perennial grass, perennial vegetative grass, perennial bunchgrass, perennial herb, perennial $\mathrm{N}_{2}$-fixing herb (legume), and perennial non- $\mathrm{N}_{2}$-fixing herb (forb) functional groups at 0.18 and $4.5 \mathrm{~m}^{2}$-scales at Rhodes, IA, USA

\begin{tabular}{|c|c|c|c|c|c|c|c|c|c|c|}
\hline \multirow[t]{2}{*}{ Functional groups } & \multicolumn{3}{|l|}{$0.18 \mathrm{~m}^{2}$} & \multicolumn{2}{|c|}{1 d.f. contrasts, $P$ value } & \multicolumn{3}{|l|}{$4.5 \mathrm{~m}^{2}$} & \multicolumn{2}{|c|}{1 d.f. contrasts, $P$ value } \\
\hline & Summit & Backslope & Toeslope & S vs. B & S vs. T & Summit & Backslope & Toeslope & S vs. B & S vs. T \\
\hline Overall & 3.2 & 4.4 & 2.5 & 0.000 & 0.001 & 11.7 & 14.3 & 10.3 & 0.030 & ns \\
\hline Annuals & 0.1 & 0.1 & 0.1 & ns & ns & 1.8 & 1.8 & 1.3 & ns & ns \\
\hline Grasses & 2.3 & 2.7 & 2.0 & 0.004 & 0.004 & 4.8 & 5.7 & 4.7 & 0.010 & ns \\
\hline Vegetative & 2.2 & 2.3 & 1.9 & ns & 0.001 & 3.8 & 3.7 & 3.8 & ns & ns \\
\hline Bunch & 0.1 & 0.3 & 0.1 & 0.010 & ns & 0.6 & 1.1 & 0.3 & 0.040 & ns \\
\hline Non- $\mathrm{N}_{2}$-fixing & 0.1 & 0.1 & 0.0 & ns & ns & 2.1 & 2.5 & 1.8 & ns & ns \\
\hline
\end{tabular}

Single degree of freedom contrasts indicate significant $(P<0.05)$ differences among positions.

nial non- $\mathrm{N}_{2}$-fixing herb, and annual-biennial functional groups was similar among summits and toeslopes at both scales.

\subsection{Grazing management effects}

Continuously and rotationally stocked (grazed) pastures supported more species overall and within each functional group than nongrazed pastures at both scales. Within the continuous, rotational, and nongrazed systems, overall species richness averaged 5.4, 4.4, and 3.3 on backslopes, $3.6,3.4$, and 2.6 on summits, and 2.9, 2.6 , and 2.1 on toeslopes, respectively, at $0.18 \mathrm{~m}^{2}$ (position $\times$ management interaction, $P \leq 0.05)$. At $4.5 \mathrm{~m}^{2}$, overall species richness averaged 14.8, 12.9, and 8.7 within the continuous, rotational, and nongrazed systems, respectively (Table 2 , position $\times$ management interaction, $P>0.05)$. Grazing increased species richness of both vegetative and bunch-type perennial grasses, $\mathrm{N}_{2}$-fixing and non $\mathrm{N}_{2}$-fixing perennial herbs, and annual-biennial grasses and forbs. Continuous and rotational stocking differed only for species richness of perennials at $0.18 \mathrm{~m}^{2}$ and perennial bunchgrasses at $0.18 \mathrm{~m}^{2}$ and $4.5 \mathrm{~m}^{2}$ (Table 2).

\section{Discussion}

Overall plant species richness and plant species richness per functional group depended on pasture position, grazing management, and scale. Backslope positions supported more species than summits and toeslopes regardless of scale. Positional differences appeared related to total vegetation production and aboveground competition. Total available herbaceous biomass averaged 1816, 2178, and $2971 \mathrm{~kg} \mathrm{ha}^{-1}$ on backslopes, summits, and toeslopes, respectively (Harmoney et al., 2001). Grazing likely enhanced species richness through reduced aboveground competition, greater heterogeneity with regards to light and soil nutrient availability, and enhanced seedling recruitment opportunities. Indeed, grazing reduced the percentage cover of smooth brome and reed canarygrass, the dominant grasses in these pastures, from $83 \%$ to $69 \%$ and enhanced heterogeneity with regards to sward heights through defoliation (Guretzky et al., 2005). An increase of scale enabled detection of a greater number of species per unit area but reduced the ability of pasture position and management to explain pasture species richness variation.

Table 2. Grazing management (continuous (C), rotational (R), and nongrazed (N) stocking) effects on species richness of overall, perennial, annual-biennial, perennial grass, perennial vegetative grass, perennial bunchgrass, perennial herb, perennial $\mathrm{N}_{2}$-fixing herb (legume), and perennial non- $\mathrm{N}_{2}$-fixing herb (forb) functional groups at 0.18 and $4.5 \mathrm{~m}^{2}$-scales at Rhodes, IA, USA

\begin{tabular}{|c|c|c|c|c|c|c|c|c|c|c|}
\hline \multirow[t]{2}{*}{ Functional groups } & \multicolumn{3}{|l|}{$0.18 \mathrm{~m}^{2}$} & \multicolumn{2}{|c|}{$\begin{array}{l}1 \text { d.f. contrasts, } \\
P \text { value }\end{array}$} & \multicolumn{3}{|l|}{$4.5 \mathrm{~m}^{2}$} & \multicolumn{2}{|c|}{$\begin{array}{l}1 \text { d.f. contrasts, } \\
P \text { value }\end{array}$} \\
\hline & Continuous & Rotational & Nongrazed & C vs. R & G vs. N & Continuous & Rotational & Nongrazed & Cvs. I & G vs. N \\
\hline Overall & 4.0 & 3.5 & 2.7 & 0.005 & 0.001 & 14.8 & 12.9 & 8.7 & ns & 0.000 \\
\hline Perennials & 3.6 & 3.2 & 2.5 & 0.012 & 0.000 & 10.6 & 9.2 & 6.7 & ns & 0.001 \\
\hline Annuals & 0.1 & 0.1 & 0.0 & ns & 0.002 & 2.4 & 2.0 & 0.5 & ns & 0.002 \\
\hline Perennial grasses & 2.6 & 2.4 & 2.1 & ns & 0.000 & 5.8 & 5.3 & 4.0 & ns & 0.000 \\
\hline Vegetative & 2.1 & 2.2 & 2.0 & ns & 0.020 & 3.9 & 3.9 & 3.5 & ns & 0.020 \\
\hline Bunch & 0.3 & 0.1 & 0.0 & 0.004 & 0.001 & 1.3 & 0.7 & 0.0 & 0.020 & 0.000 \\
\hline Perennial herbs & 0.7 & 0.6 & 0.4 & ns & 0.002 & 5.5 & 4.7 & 3.3 & ns & 0.020 \\
\hline Legumes & 0.6 & 0.5 & 0.3 & ns & 0.001 & 2.8 & 2.5 & 1.8 & ns & 0.080 \\
\hline Forbs & 0.1 & 0.1 & 0.0 & ns & 0.030 & 2.7 & 2.3 & 1.5 & ns & 0.020 \\
\hline
\end{tabular}

Single degree of freedom contrasts indicate significant $(P<0.05)$ differences among systems. 
Grazing itself largely accounted for species richness differences among stocking systems. Both continuously and rotationally stocked pastures had greater species richness than nongrazed pastures, effects that extended across scales and functional types. Grazer preference for taller, dominant vegetative grasses or greater tolerance of defoliation may have increased the presence of subdominant vegetative and bunch-type grasses, and disturbance may have created conditions favorable to recruitment of annual-biennials and perennial forbs, functional groups that tend to exhibit good gap colonization abilities (Tracy and Sanderson, 2000). Plant traits that tend to be associated with gap colonization ability include good germination, short-life cycles, early flowering, and heavy allocation to reproduction (Pywell et al., 2003). Litter accumulation, aboveground competition, and accompanied low light availability at soil surfaces have limited seedling recruitment and colonization opportunities and species richness in nongrazed situations (Hartnett et al., 1996; Tilman, 1997; Collins et al., 1998). Grasses that have the ability to tiller and spread rapidly vegetatively have a competitive advantage in nongrazed situations through decreased the risk of plant mortality and the position of buds below or close to the soil surface (Pywell et al., 2003).

Overall species richness compared favorably with values reported in other studies of temperate pastures with variability likely reflecting site, management, and scale differences. Thirty-nine species were found when samples were summed across landscape positions, stocking systems, and pasture replicates to form an area of $162 \mathrm{~m}^{2}$ (Figure 1). Tracy and Sanderson (2000) reported that pastures across the northeastern United States supported, on average, 32 species per $1000 \mathrm{~m}^{2}$. Non- $\mathrm{N}_{2}$-fixing, perennial, biennial, and annual forbs accounted for $90 \%$ of the pasture species in the latter study compared to $60 \%$ of the species in this study. Dodd et al. (2004) noted that hill country pasture composition in New Zealand typically comprises $15-25$ species $\mathrm{m}^{-2}$ with current composition largely reflecting effects of fertilizer and grazing management. Like temperate North American pastures, nearly all of the pasture species had European origins (Dodd et al., 2004). White et al. (2004) surmised a need for a functionally diverse plant community over the entire managed area rather than high localized species diversity. Although this experiment was not designed to test the effects of individual species, functional types, or overall species diversity, previous results suggest that enhancing legume content and diversity on sloped positions improves forage production spatially and temporally and enhances the $\mathrm{N}$ economy of low-input pasture systems (Harmoney et al., 2001).

\section{References}

Collins, S.L., Knapp, A.K., Briggs, J.M., Blair, J.M., Steinauer, E.M., 1998. Modulation of diversity by grazing and mowing in native tallgrass prairie. Science 280, 745-747.

Crawley, M.J., Brown, S.L., Heard, M.S., Edwards, G.R., 1999. Invasion-resistance in experimental grassland communities: species richness or species identity? Ecol. Lett. 2, 140-148.

Dodd, M.B., Barker, D.J., Wedderburn, M.E., 2004. Plant diversity effects on herbage production and compositional changes in New Zealand hill country pastures. Grass Forage Sci. 59, 29-40.

Dukes, J.S., 2002. Species composition and diversity affect grassland susceptibility and response to invasion. Ecol. Appl. 12, 602-617.

Guretzky, J.A., Moore, K.J., Brummer, E.C., Burras, C.L., 2005. Species diversity and functional composition of pastures that vary in landscape position and grazing management. Crop Sci. 45, 282-289.

Harmoney, K.R., Moore, K.J., Brummer, E.C., Burras, C.L., George, J.R., 2001. Spatial legume composition and diversity across seeded landscapes. Agron. J. 93, 992-1000.

Hartnett, D.C., Hickman, K.R., Fischer Walter, L.E., 1996. Effects of bison grazing, fire, and topography on floristic diversity in tallgrass prairie. J. Range Manage. 49, 413-420.

Hector, A., Beale, A.J., Minns, A., Otway, S.J., Lawton, J.H., 2000. Consequences of the reduction of plant diversity for litter decomposition: effects through litter quality and microenvironment. Oikos 90, 357-371.

Hector, A., Schmid, B., Beierkuhnlein, C., Caldeira, M.C., Diemer, M., Dimitrakopoulos, P.G., Finn, J.A., Freitas, H., Giller, P.S., Good, J., Harris, R., Högberg, P., Huss-Danell, K., Joshi, J., Jumpponen, A., Körner, C., Leadley, P.W., Loreau, M., Minns, A., Mulder, C.P.H., O'Donovan, G., Otway, S.J., Pereira, J.S., Prinz, A., Read, D.J., Scherer-Lorenzen, M., Schulze, E.-D., Siamantziouras, A.-S.D., Spehn, E.M., Terry, A.C., Troumbis, A.Y., Woodward, F.I., Yachi, S., Lawton, J.H., 1999. Plant diversity and productivity experiments in European grasslands. Science 286, 1123-1127.

Hooper, D.U., 1998. The role of complementarity and competition in ecosystem responses to variation in plant diversity. Ecology 79, 704-719.

Hooper, D.U., Vitousek, P.M., 1999. The effects of plant composition and diversity on ecosystem processes. Science 277, 1302-1305.

Knops, J.M.H., Wedin, D., Tilman, D., 2001. Biodiversity and decomposition in experimental grassland ecosystems. Oecologia 126, $429-433$.

Oelmann, D.B., 1981. Soil Survey of Marshall County, Iowa. USDA-SCS. U.S. Government Printing Office, Washington, DC.

Pywell, R.F., Bullock, J.M., Roy, D.B., Warman, L., Walker, K.J., Rothery, P., 2003. Plant traits as predictors of performance in ecological restoration. J. Appl. Ecol. 40, 65-77.

Sanderson, M.A., Skinner, R.H., Barker, D.J., Edwards, G.R., Tracy, B.F., Wedin, D.A., 2004. Plant species diversity and management of temperate forage and grazing land ecosystems. Crop Sci. 44, 1132-1144.

Tilman, D., 1997. Community invasibility, recruitment limitation, and grassland biodiversity. Ecology 78, 81-92.

Tilman, D., Reich, P.B., Knops, J.,Wedin, D., Mielke, T., Lehman, C., 2001. Diversity and productivity in a long-term grassland experiment. Science 294, 843-845.

Tracy, B.F., Sanderson, M.A., 2000. Patterns of plant species richness in pasture lands of the northeast United States. Plant Ecol. 149, 169-180.

White, T.A., Barker, D.J., Moore, K.J., 2004. Vegetation diversity, growth, quality, and decomposition in managed grasslands. Agric. Ecosyst. Environ. 101, 73-84. 